\title{
Дослідження основних показників економічного розвитку України на ринку інвестицій
}

\author{
(Представлено: д.е.н., проф. Власенко І.В.)
}

\begin{abstract}
У статті визначено компоненти інвестиційної привабливості краӥни, розкрито значення основних економічних показників інвестиційного забезпечення розвитку економіки України, зокрема, проаналізовано такі показники: індекс інвестиційної привабливості; показник легкості ведення бізнесу; індекс конкурентоспроможності. Визначено важливість залучення інвестицій в економіку краӥни, приділено увагу перешкодам на шляху реалізаџї проектів інвестування економіки, розглянуто перспективи розвитку при ефективному використанні інвестицій, проаналізовано динаміку індексу інвестиційної привабливості України. Здійснено аналітичний огляд позицій України у ключових рейтингах, щуо суттєво впливають на інвестиційний імідж держави. У статті вказано рівень інвестиційної привабливості України згідно з методикою Європейської Бізнес Асоціаџіï. Зазначено, щзо основними факторами, які впливають на інвестиційну привабливість, $\epsilon$ : внутрішня політична стабільність країни, усталеність нормативно-правової бази щодо підприємницької та інвестиційної діяльності, щуо гарантує недоторканість приватної власності, характер та темпи зростання економіки, стан фондового ринку, фінансово-кредитної системи, місткість $і$ платоспроможність внутрішнього ринку, природні ресурси, сочіально-культурні фактори країни. Визначено ключові проблеми покращення інвестииійної привабливості. Визначається взаємозалежність між рейтинговою оцінкою та інвестиційною привабливістю краӥни. Зроблено висновки щьодо інвестиційного потенціалу крайни. Сформульовано авторські пропозиції щзодо підвищення інвестииійної привабливості України.

Ключові слова: інвестиційна привабливість; індекс інвестиційної привабливості; показник легкості ведення бізнесу; індекс конкурентоспроможності.
\end{abstract}

Актуальність теми. Одним із важливих чинників формування потужної економіки будь-якої країни $€$ інвестиції. Вони дозволяють розвивати ту чи іншу галузь економіки, вивести її на новий рівень, поліпшити економічне та фінансове становище країни в цілому. Залучення саме довгострокових іноземних інвестицій, а також активізація діяльності з їх «просування» протягом майже усіх років незалежності України було одним із пріоритетних завдань їі економічної політики, що визначалися низкою офіційних документів. Проте, на жаль, сьогодні результати є невтішними, і великі західні інвестори з обережністю ставляться до України. Тому необхідно корегувати всі фактори, які негативно впливають на формування сприятливого інвестиційного клімату, та підсилювати ті фактори, які є позитивними. Дослідження показника інвестиційної привабливості є важливим в умовах сучасного розвитку України та зміни 䜣 геополітичних векторів і має як теоретичне, так і практичне значення.

Аналіз останніх досліджень та публікації, на які спирається автор. Питанням інвестиційного забезпечення розвитку економіки не один рік займається низка вчених та науковців. Серед них варто виокремити В.О. Вакулову, яка досліджувала складові інвестиційної привабливості та перспективи їх використання в економічному аналізі; О.I. Маслак, В.А. Таловер здійснили комплексне оцінювання інвестиційної привабливості України, І.О. Бланк в цілому досліджував інвестиції як явище та алгоритми інвестиційних процесів. Гусаров М.Ю. обгрунтував вплив факторів конкурентоспроможності на інвестиційну привабливість регіонів країни [2].

Мета статті полягає в аналізі індексу інвестиційної привабливості як важливого фактора формування розвиненої економіки України, а також у пошуку способів зміцнення позицій країни на ринку інвестицій.

Викладення основного матеріалу дослідження. Все більшу актуальність сьогодні, за браком вільних фінансових ресурсів вітчизняних підприємств, отримують інвестиції, а на тлі фінансової нестабільності в країні - іноземні інвестиції. Саме іноземний капітал став каталізатором інвестиційної активності у більшості розвинутих європейських країн у періоди розвитку та структурної перебудови економіки.

$40 \%$ топ-менеджерів очікують поліпшення бізнес-клімату протягом наступного півріччя. Тоді як настрої підприємців щодо поточного стану інвестклімату не настільки оптимістичні. Такими $є$ висновки Індексу інвестиційної привабливості України, який двічі на рік вимірює Свропейська Бізнес Асоціація.

Беззаперечним є той факт, що в Україні існує низка інвестиційно привабливих факторів, які сприяють розширенню iï інвестиційних зв'язків: великий ємний та фактично конкуренто необмежений внутрішній ринок з більшості товарних позицій; географічне розташування на перетині основних транспортних 
шляхів між Європою та Азією; порівняно дешева та водночас кваліфікована робоча сила; науковий потенціал; розвинена інфраструктура (наявність портів, мостів, летовищ, складів, систем зв'язку, водопостачання) тощо.

Інвестиційна привабливість країни - це сукупність політичних, соціальних, інституціональних, екологічних, макро- і мікроекономічних умов функціонування національної економіки, що забезпечують стабільність інвестиційної діяльності вітчизняних і зарубіжних інвесторів [7].

За результатами нової хвилі опитування, у другій половині 2019 року Індекс склав 2,95 бала із 5 можливих та продовжує перебувати у негативній площині. Хоча порівнянно з попереднім періодом показник Індексу дещо зріс (2,85 у першій половині 2019 року) (рис. 1) [3].

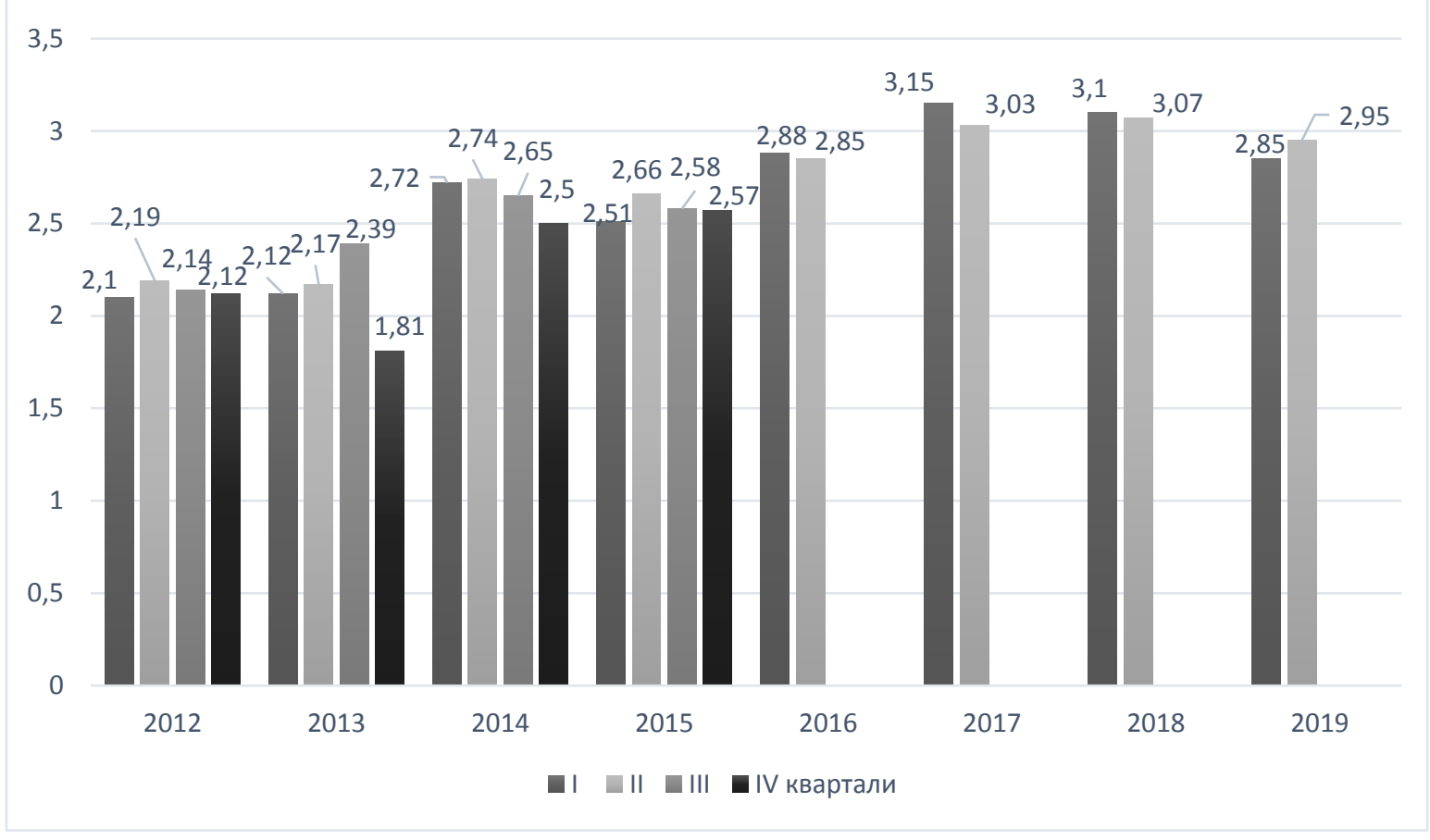

Рис. 1. Динаміка Індексу інвестиційної привабливості України протягом 2012-2019 років

Приріст прямих інвестицій в Україну в I кварталі 2019 року склав 45,5 млн. дол. Для порівняння, показник попереднього періоду становив 3,07 бала та демонстрував нейтральне ставлення інвесторів до бізнес-клімату країни. Результати опитування вказують на відчутне погіршення настроїв бізнесу. Так під час минулої хвилі опитування кількість незадоволених інвестиційним кліматом становила 40 \%, зараз їх кількість зросла до 57 \%. Відсоток задоволених поточним станом також зменшився, наразі тільки 19 \% топменеджерів вважають бізнес-середовище сприятливим, натомість наприкінці 2018 року таких було $25 \%$ [5].

Серед позитивних моментів, які спостерігав бізнес останні пів року, бізнесмени зазначили лібералізацію валютного законодавства, стабільність національної валюти, демократичні президентські вибори, зниження рівня інфляції, продовження діалогу з МВФ. Однак до «старих» проблем, як-от корупція, недовіра до судової системи, відтік робочої сили, додалися відчутна політична й економічна турбулентності, які турбують підприємців та змушують вести бізнес в умовах невизначеності. Серед топпроблем інвестори вже традиційно зазначили високий рівень корупції (83 \% респондентів критично незадоволені станом справ), недовіру до судової системи - 77 \%, а також відсутність земельної реформи та тіньову економіку - по $66 \%$ [3].

До того ж бізнес не поспішає робити оптимістичних передбачень на майбутнє. Так 54 \% керівників компаній вагаються, чи буде Україна вигідним ринком для інвестування у найближчі 6 місяців. $47 \%$ вважають, що умови роботи в їхній індустрії не зазнають жодних змін у найближче півріччя. Ще 35 \% інвесторів прогнозують, що бізнес-клімат в Україні залишиться незмінним у 2-му півріччі 2019 року, водночас 35 \% очікують незначного покращення.

Проте, крім Індексу інвестиційної привабливості, потенційним інвесторам слід враховувати такий показник, як «ведення бізнесу». Рейтинг «Doing Business» - це результат щорічного дослідження, що оцінює простоту ведення підприємницької діяльності за десятьма показниками у 190 країнах світу. Компоненти рейтингу оцінюють нормативні акти, що регулюють діяльність малих і середніх підприємств протягом усього життєвого циклу, та їх фактичне використання на практиці [11]. 
Україна піднялася на сім пунктів у рейтингу легкості ведення бізнесу «Doing business-2020 року», який щорічно публікує Всесвітній банк, і зайняла 64 позицію із 190 країн (рис. 2) [9].

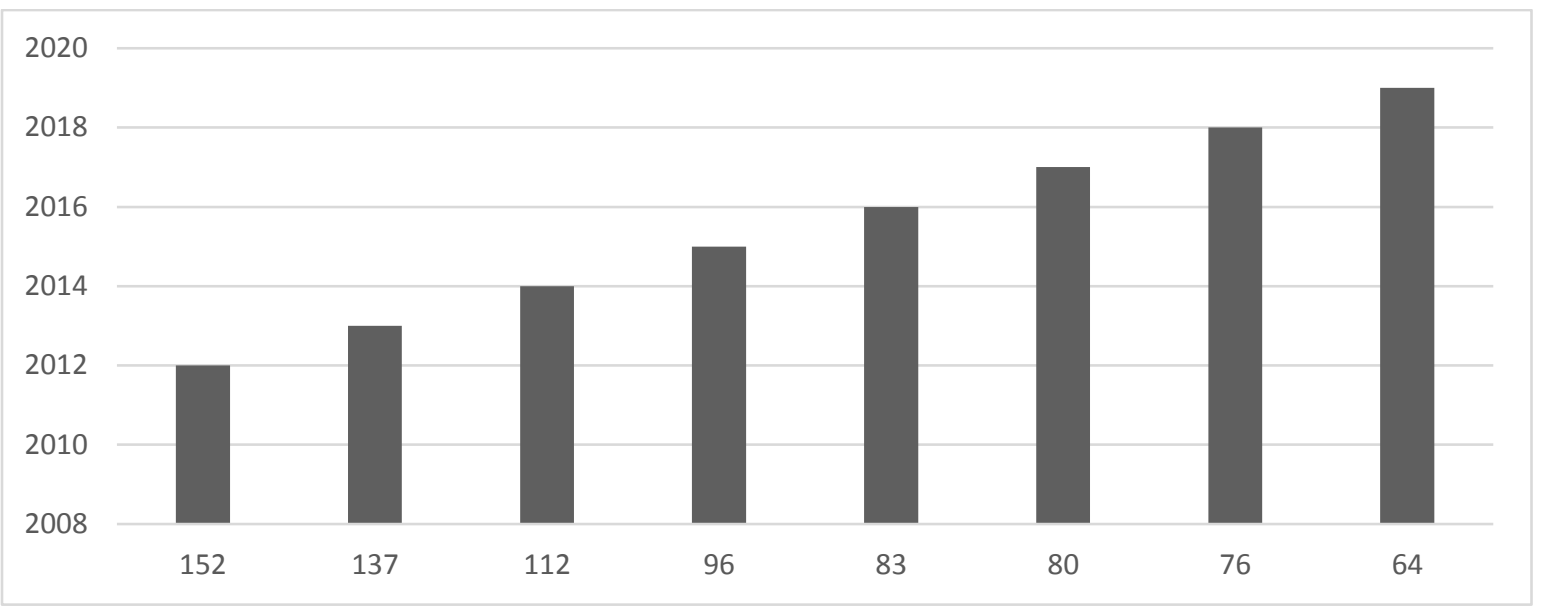

Рис. 2. Динаміка положення Украӥни в рейтингу легкості ведення бізнесу Doing business за 2012-2019 роки

Аналізуючи рисунок 2 необхідно зауважити, що спостерігається позитивна тенденція положення України серед інших країн у цьому рейтингу. Якщо порівнювати 2012 та 2019 роки, то спостерігаємо очевидне покращення ситуації, адже за цей період позиція України в рейтингу покращилася (зі 152 на 64 місце).

Згідно з даними звіту Світового банку, в 2019 році Україна поліпшила свої показники щодо 6310 індикаторів, які враховуються фахівцями Світового банку при складанні рейтингу.

Як повідомляє пресслужба уряду, найбільший прогрес Україна продемонструвала за компонентом «Захист міноритарних акціонерів» (+27 пунктів) - завдяки відкриттю інформації про кінцевих бенефіціарів і компонентом «Отримання дозволу на будівництво» (+10 пунктів) - за рахунок усунення вимог до найму незалежного проектанта й інженера технагляду, введення системи онлайн-повідомлень, а також зменшення вартості дозволів на будівництво в межах Києва.

На підвищення позицій у рейтингу вплинули позитивні зміни таких компонентів [9]:

- «Підключення до електромереж»: спрощення підключення до електромереж і впорядкування технічних умов, а також впровадження географічної інформаційної системи. Крім того, покращена надійність електропостачання завдяки механізму компенсації відключення;

- «Міжнародна торгівля»: спрощення вимог до сертифікації окремих промислових товарів;

- «Реєстрація майна»: підвищення прозорості системи управління земельними ресурсами та спрощення реєстрації майна;

- «Доступ до кредитів»: покращено доступ до кредитної інформації через створення нового Національного реєстру кредитів у Національному банку України.

Як бачимо, ці два показники є досить суперечливими між собою, оскільки Індекс інвестиційної привабливості знаходиться на досить низькому рівні, в той час як за показником «легкість ведення бізнесу» Україна зміцнила позиції. Така різниця є результатом формування негативного іміджу України як привабливої для інвестицій країни. Основними факторами, які впливають на інвестиційну привабливість, $€$ : внутрішня політична стабільність країни, усталеність нормативно-правової бази щодо підприємницької та інвестиційної діяльності, що гарантує недоторканість приватної власності, характер та темпи зростання економіки, стан фондового ринку, фінансово-кредитної системи, місткість і платоспроможність внутрішнього ринку, природні ресурси, соціально-культурні фактори країни [1].

До факторів, які формують негативну репутацію, належать:

- політична нестабільність;

- геополітична невизначеність України;

- високий рівень інфляції;

- відтік робочої сили закордон;

- інвестування в «стандартні» галузі тощо.

До так званих «стандартних» галузей слід зарахувати аграрну, металургію та торгівлю. Проте найбільш динамічно зростаючою галуззю в сучасному світі є сфера послуг та ІТ-технології. Як зазначає Сергій Савчук - директор P\&S Asset Management: «Найбільш перспективні галузі інвестування - це напрями діяльності у сфері послуг» [10].

Для розвитку вказаних сфер Україна має всі необхідні ресурси: кваліфіковані кадри, наявний багатий туристичний потенціал тощо. Однак низький Індекс інвестиційної привабливості нівелює всі ці ресурси. 
Показник «Doing business» на сьогодні є дієвим для внутрішнього підприємництва, оскільки Індекс інвестиційної привабливості $є$ негативним. Активний розвиток внутрішнього бізнесу в Україні буде сприяти загальному економічному розвитку, що зі свого боку буде позитивно впливати на формування сприятливого інвестиційного клімату на міжнародній арені.

Не менш важливим для оцінювання міжнародної економічної позиції України є Глобальний індекс конкурентоспроможності країн (Global Competitiveness Index), що характеризує рейтинг, розрахований за методикою Світового Економічного Форуму (World Economic Forum). При складанні Глобального рейтингу конкурентоспроможності оцінюються більш ніж 100 складових конкурентоспроможності. Україна в 2019 році втратила дві позиції в Індексі глобальної конкурентоспроможності (Global Competitiveness Index, GCI) Всесвітнього економічного форуму (ВЕФ) й опустилася на 85 місце з 141 країни. Відомо, що в 2012 році Україна в GCI була 73 зі 144 країн, в 2013 опустилася на 84 позицію зі 148 країн, після Революції гідності піднялася одразу на 76 місце зі 144 країн, проте потім спустилася на 79 позицію зі 140 країн, а в 2016 році - на 85 позицію зі 138. У 2017 році країна піднялася на 81 місце в рейтингу зі 137 країн, а в 2018 році спустилася на 83 позицію, в 2019 році - на 85 зі 140 країн (табл. 1) [8].

Рейтинг краӥн за Індексом конкурентоспроможності у 2018-2019 роках

Таблиия 1

\begin{tabular}{|c|c|c|c|c|}
\hline \multirow{2}{*}{ Країна } & \multicolumn{2}{|c|}{ Позиція в рейтингу } & \multicolumn{2}{c|}{ Значення Індексу } \\
\cline { 2 - 5 } & $\mathbf{2 0 1 8}$ рік & $\mathbf{2 0 1 9}$ рік & $\mathbf{2 0 1 8}$ рік & $\mathbf{2 0 1 9}$ рік \\
\hline Сінгапур & 3 & 1 & 5,81 & 5,86 \\
\hline США & 2 & 2 & 5,72 & 5,71 \\
\hline Нідерланди & 4 & 4 & 5,70 & 5,75 \\
\hline Швейцарія & 1 & 5 & 5,57 & 5,51 \\
\hline Японія & 9 & 6 & 5,57 & 5,65 \\
\hline Німеччина & 5 & 7 & 5,55 & 5,50 \\
\hline Україна & 83 & 85 & 4,10 & 4,00 \\
\hline
\end{tabular}

Довідка: розробка автора на основі джерел [12-13]

Із найближчих сусідів Польща та Росія залишилися на попередніх позиціях - 37 та 43 місце відповідно, Румунія піднялася на 51 місце (+1), Угорщина на 47 (+1), Молдова на $86(+2)$, Словаччина спустилася до 42 місця (-1) [8].

Згідно зі щорічним звітом ВЕФ, основний регрес зафіксовано у сфері фінансових систем, у якій рейтинг України опустився на 19 позицій - до 136 місця, й у сфері охорони здоров'я - на 9 позицій, до 101 місця.

Координування використання переваг кожної конкретно взятої території сприяло б підвищенню інвестиційної активності. Створення єдиного реєстру пріоритетних інвестиційних проєктів дозволить розширити пошук і залучення зацікавлених осіб. Необхідне також створення систем гарантій i співробітництва щодо забезпечення зворотності позикових коштів, страхування інвестиційних ризиків, розробки механізму запозичень під реалізацію довгострокових інвестиційних проектів.

Перспективи розвитку економіки залежать також від економічної політики держави, яка має забезпечувати динамічну рівновагу економіки та стійкі темпи приросту національного доходу, здійснювати доцільні зміни в структурі суспільного виробництва. Не менш важливим завданням $є$ ефективне використання інвестицій.

Здійснення у регіонах децентралізації інвестиційних фондів та інвестування конкретних проектів пріоритетного напряму, а також забезпечення жорсткого контролю виконання інвестованих проектів, дозволить покращити стан розвитку економіки, зміцнити позиції за основними економічними показниками на ринку інвестицій.

Успішне функціонування підприємств і досягнення стратегічних переваг в умовах конкуренції значною мірою залежать від результативності їхньої інноваційної діяльності. У свою чергу, результативність інноваційної діяльності підприємств визначається, насамперед, наявністю необхідних внутрішніх і зовнішніх джерел фінансування інновацій, можливістю їхньої швидкої мобілізації, зацікавленістю інвестора в підтримці інноваційного розвитку [6].

Для подальшого покращення інвестиційного клімату України актуальним на сьогодні $є$ питання удосконалення правової та організаційної бази для підвищення дієздатності механізмів забезпечення сприятливого інвестиційного клімату й формування основи збереження та підвищення конкурентоспроможності вітчизняної економіки.

Приєднання України до Декларації ОЕСР про міжнародні інвестиції і багатонаціональні підприємства та набуття членства в Інвестиційному комітеті ОЕСР надасть такі суттєві переваги для країни, а саме:

- свідчитиме про запровадження Україною міжнародних стандартів здійснення інвестиційної діяльності; 
- $\quad$ сприятиме залученню прямих іноземних інвестицій шляхом усунення обмежень щодо секторів, в яких іноземне інвестування заборонене, та забезпечення національного режиму для транснаціональних корпорацій (далі - ТНК) відповідно до системи розвитку міжнародних стандартів у регулюванні відносин ТНК із країнами, що приймають їхні інвестиції;

- сприятиме поліпшенню конкурентного середовища та впливу на впровадження і розповсюдження інновацій;

- сприятиме реалізації принципів та стандартів соціальної відповідальності бізнесу згідно 3 керівними принципами ОЕСР щодо ведення відповідального бізнесу.

Виконання всіх цих умов є необхідним та актуальним кроком економіки України. Це б дозволило зміцнити позиції України за такими показниками, як Індекс інвестиційної привабливості, показник легкості ведення бізнесу Doing Business, а також зміцнити конкурентні позиції на інвестиційному ринку.

Висновки та перспективи подальших досліджень. Отже, проаналізувавши рейтингові позиції України в міжнародних дослідженнях економічного розвитку країн, можна зауважити наступне.

На жаль, як ми бачимо, позиції України в міжнародних економічних рейтингах вже тривалий час залишаються досить слабкими. Навіть серед країн Східної Європи наша країна займає далеко не найкращі позиції. Разом з тим, в України є значний інвестиційний та людський потенціал, ефективне використання якого може бути передумовою поступового підвищення міжнародної конкурентоспроможності країни у світових рейтингах. Стратегічний розвиток України має бути спрямований на продовження проведення ефективних реформ щодо зміцнення вітчизняної економіки та підвищення ії міжнародного іміджу. Зокрема, Україні слід зосередити значну увагу на зміцненні фінансових ринків, вдосконаленні судової системи, вирішенні конфліктів з країною-агресором, подоланні корупції та бюрократії. Зусилля держави слід також спрямувати на вирішення проблем в комерційній сфері та, тим самим, формування сприятливого бізнес-середовища. У цій сфері реформи мають бути направлені на створення максимальної прозорості використання інвестиційних ресурсів, вибір ефективних інструментів податкового навантаження на бізнес з іноземним капіталом, розвиток інвестиційно-привабливих сфер (сфера послуг та інформаційних технологій). Результати проведеного дослідження можуть бути використані для проведення подальших наукових досліджень щодо оцінки та аналізу інвестиційної привабливості України, а також бути основою для розробки заходів щодо підвищення позицій України у міжнародних рейтингах та покращення соціально-економічного становища.

\section{Список використаної літератури:}

1. Антонюк К.Г. Фактори інвестиційної привабливості туристичної сфери України / К.Г. Антонюк // Modern Economics. - 2019. - Вип. 13. - С. 168-173.

2. Гусарова М.Ю. Вплив «жорстких» та «м'яких» факторів конкурентоспроможності на інвестиційну привабливість регіонів країни / М.Ю. Гусарова // Економічний вісник Запорізької державної інженерної академії. - 2017. - Вип. 1 (2). - С. 47-50.

3. Індекс інвестиційної привабливості України [Електронний ресурс]. - Режим доступу : https://finpost.com.ua/news/15598

4. Індекс корупції [Електронний ресурс]. - Режим доступу : https://nv.ua/ukr/biz/economics/investiciynaprivablivist-ukrajini-vidchutno-znizilasya-50029981.html.

5. Критично знизився показник індексу інвестиційної привабливості України [Електронний ресурс]. - Режим доступу : https://agropolit.com/news/12720-kritichno-znizivsya-pokaznik-indeksu-investitsiynoyi-privablivostiukrayini.

6. Кучерявенко С.Ю. Сутність інноваційно-інвестиційного розвитку підприємств сфери послуг / С.Ю. Кучерявенко // Теоретичні і практичні аспекти економіки та інтелектуальної власності. - 2015. Вип. 2, Т. 1. - С. 44-47.

7. Муніципальні інвестиції та кредити [Електронний ресурc]. - Режим доступу : http://www.infolibrary.com.ua/books-text-2488.html.

8. Україна опустилася на 85-те місце в щорічному рейтингу конкурентоспроможності WEF [Електронний pecypc]. - Режим доступу : https://ua.interfax.com.ua/news/economic/617843.html.

9. Україна піднялася в рейтингу Doing business-2020 [Електронний ресурс]. - Режим доступу : https://uanews.liga.net/economics/news/ukraina-pidnyalasya-v-reytingu-doing-business-2020.

10. Фонди прямих інвестицій ідуть в сферу послуг [Електронний ресурс]. - Режим доступу : http://news.finance.ua/ua/ /1/0/all/2010/09/06/208650.

11. Doing Business [Electronic recourse]. - Access mode : http://www.me.gov.ua/Documents/Detail?lang=ukUA\&id=05376d6c-3772-4027-ac6f 73e33e2905a8\&title=DoingBusiness2019.

12. The Global Competitiveness Report 2017-2018 [Electronic recourse]. - Access mode http://www3.weforum.org/docs/GCR2017-2018/05FullReport/TheGlobalCompetitivenessReport2017-2018.pdf.

13. The Global Competitiveness Report 2019 [Electronic recourse]. - Access mode http://www3.weforum.org/docs/WEF_TheGlobalCompetitivenessReport2019.pdf. 


\section{References:}

1. Antonjuk, K.G. (2019), «Faktory investycijnoi' pryvablyvosti turystychnoi' sfery Ukrai'ny», Modern Economics, Issue 13, pp. 168-173.

2. Gusarova, M.Ju. (2017), «Vplyv «zhorstkyh» ta «m'jakyh» faktoriv konkurentospromozhnosti na investycijnu pryvablyvist' regioniv krai'ny», Ekonomichnyj visnyk Zaporiz'koi' derzhavnoi' inzhenernoi' akademii', Issue 1 (2), pp. 47-50.

3. Indeks investycijnoi' pryvablyvosti Ukrai'ny (2019), [Online], available at: https://finpost.com.ua/news/15598

4. Indeks korupcii' (2019), [Online], available at: https://nv.ua/ukr/biz/economics/investiciyna-privablivist-ukrajinividchutno-znizilasya-50029981.html

5. Krytychno znyzyvsja pokaznyk indeksu investycijnoi' pryvablyvosti Ukrai'ny (2019), [Online], available at: https://agropolit.com/news/12720-kritichno-znizivsya-pokaznik-indeksu-investitsiynoyi-privablivosti-ukrayini

6. Kucherjavenko, S.Ju. (2015), «Sutnist' innovacijno-investycijnogo rozvytku pidpryjemstv sfery poslug», Teoretychni i praktychni aspekty ekonomiky ta intelektual'noi' vlasnosti, Issue 2, pp. 44-47.

7. Municypal'ni investycii' ta kredyty (2019), [Online], available at: http://www.info-library.com.ua/books-text2488.html

8. Ukrai'na opustylasja na 85-te misce v shhorichnomu rejtyngu konkurentospromozhnosti WEF (2019), [Online], available at: https://ua.interfax.com.ua/news/economic/617843.html

9. Ukrai'na pidnjalasja $\mathrm{v}$ rejtyngu Doing business-2020 (2019), [Online], available at: https://uanews.liga.net/economics/news/ukraina-pidnyalasya-v-reytingu-doing-business-2020

10. Fondy prjamyh investycij idut' $\mathrm{v}$ sferu poslug (2019), [Online], available at: http://news.finance.ua/ua/ /1/0/all/2010/09/06/208650

11. Doing Business (2019), [Online], available at: http://www.me.gov.ua/Documents/Detail?lang=ukUA\&id=05376d6c-3772-4027-ac6f 73e33e2905a8\&title=DoingBusiness2019

12. The Global Competitiveness Report 2017-2018 (2019), [Online], available at: http://www3.weforum.org/docs/GCR2017-2018/05FullReport/TheGlobalCompetitivenessReport2017-2018.pdf

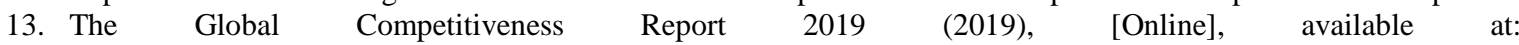
http://www3.weforum.org/docs/WEF_TheGlobalCompetitivenessReport2019.pdf

Антонюк Катерина Геннадіївна - асистент Вінницького торговельно-економічного інституту КНТЕУ, аспірант КНТЕУ.

Наукові інтереси:

- інвестиційне забезпечення розвитку туризму;

- розвиток сфери послуг в Україні;

- економіка та управління підприємством. 